Onder redactie van:

Prof. mr. dr. B.M.E.M. Schols

Prof. mr. dr. W. Burgerhart

Prof. mr. dr. F.W.J.M. Schols

Mr. F.M.H. Hoens

Mr. G.A. Tuinstra

Mr. J.Th.M. Diks

Mr. M.J.P. Schipper

Mr. dr. N.V.C.E. Bauduin

Mr. E.C.E. Schnackers

Mr. dr. J.W.A. Rheinfeld

\section{Advotip}

Erfrecht voor de advocaat

\title{
Vergeet de begunstiging krachtens levensverzekering niet!
}

\section{Erfstelling en begunstiging gaan 'hand in hand' (II)}

In AdvoTip 2017-17 was de uitspraak van Hof Amsterdam (9 mei 2017, ECLI:NL:GHAMS:2017:1751) aanleiding om in te gaan op de erfopvolging bij versterf en de begunstiging bij levensverzekering. Inmiddels heeft ook de Hoge Raad (6 juli 2018, ECLI:NL:HR:2018:1102, NJ 2018/441, m.nt. L.C.A. Verstappen) zich over de destijds besproken kwestie gebogen; reden om wederom stil te staan bij deze zaak.

Volledigheidshalve kort de casus: man $Y$ is twee keer gehuwd geweest. Beide huwelijken eindigen door echtscheiding. In 2006 is $Y$ ongehuwd gaan samenwonen met mevrouw X. In 2006 maakt hij een testament waarin hij, onder meer, mevrouw X tot enig erfgenaam benoemt en bij gelijktijdig (dan wel haar voor)overlijden, het KWF. In het testament is ook geregeld dat eventuele legitimaire vorderingen van zijn kinderen nietopeisbaar zijn tijdens het leven van mevrouw X (zijnde zijn andere levensgezel als bedoeld in art. 4:82 BW). In 2012 vult hij de erfstelling in zoverre aan dat expliciet wordt vermeld dat de benoeming van partner $\mathrm{X}$ tot enig erfgenaam:

'wordt gedaan om fiscale redenen en ter voldoening aan mijn dringende verplichting om mijn partner goed verzorgd achter te laten.' (Curs. FH)

De levensverzekering-technische kant van de casus ziet op een tweetal polissen van levensverzekeringen, afgesloten in respectievelijk 1996 en 1999. Polis I kent als begunstigden achtereenvolgens: de verzekeringsnemer, zijn echtgenote, zijn kinderen en zijn erfgenamen. In polis II waren dat: zijn weduwe, zijn kinderen en zijn erfgenamen.

Bij het overlijden van $Y$ in 2013 meent mevrouw $X$ dat zij als enig erfgenaam recht heeft op de levensverzekering-uitkeringen. De verzekeringsmaatschappij weigert om deze aan haar over te maken en verwijst naar de begunstigingclausules in de polis en de leer van het zelfstandig recht. Volgens die leer behoren, als een derde begunstigde is, de uitkeringen niet tot de nalatenschap van de overledene. Niet enig erfgenaam X, maar (bij ontbreken van een echtgenoot/weduwe) de in de polissen begunstigde kinderen zijn dan de verkrijgers. Via de Rechtbank Noord-Holland belandt de zaak bij het Hof Amsterdam (9 mei 2017, ECLI:NL:GHAMS:2017:1751).

Het hof oordeelt dat de zaak uiteindelijk een uitlegkwestie is: wat was de bedoeling van de erflater/verzekeringnemer? Het hof meent dat bepalend is de bedoeling van de verzekeringnemer ten tijde van de aanwijzing. Bij het achterhalen daarvan kunnen ook 
een rol spelen eventuele verklaringen en gedragingen van de verzekeringnemer buiten de schriftelijke mededeling aan de verzekeraar. Dit kunnen onder omstandigheden ook verklaringen en gedragingen van een latere datum zijn, dat wil zeggen van na de aanwijzing zelf. lets anders is, zo het hof, of uit de latere verklaringen en gedragingen kan worden afgeleid dat de bedoeling van de erflater was dat de polissen ten gunste van mevrouw $X$ zouden moeten worden uitgekeerd. Immers, omdat zij elkaar op dat moment nog niet kenden, kon ten tijde van het sluiten van de polissen en de aanwijzing de bedoeling van verzekeringnemer $Y$ niet zijn om $X$ als begunstigde aan te wijzen. Het Hof Amsterdam volgt de vrouw dan ook niet in haar betoog dat uit de testamentaire onterving van de kinderen blijkt dat $Y$ hen ook wilde uitsluiten als begunstigden voor de levensverzekeringuitkering.

lets anders is of, gezien de concrete feiten en omstandigheden (goede verzorging en een huis dat 'onder water stond') de derogerende werking van de redelijkheid en billijkheid met zich brengt dat de kinderen geen rechten kunnen ontlenen aan de begunstiging in de polissen. Het Hof Amsterdam concludeert:

'Uit het voorgaande volgt naar het oordeel van het hof dat [geïntimeerden] in de gegeven en hiervoor genoemde omstandigheden naar maatstaven van redelijkheid en billijkheid geen rechten kunnen ontlenen aan de begunstiging en dat [appellante] als erfgename als opvolgend begunstigde heeft te gelden. [...]' (Curs. FH)

Ook de Hoge Raad is kraakhelder:

'3.3.3 Het hof heeft in [...] geoordeeld dat de door [X] gestelde (latere) verklaringen en gedragingen van erflater niet meebrengen dat het ten tijde van de aanwijzing zijn bedoeling was om [verweerster] als begunstigde aan te wijzen. Het oordeel van het hof in rov. 3.10 komt erop neer dat die latere verklaringen en gedragingen wel tot de conclusie voeren dat erflater op een later moment (en tot aan zijn overlijden) de bedoeling had dat $[X]$ als begunstigde van de levensverzekeringen zou gelden en dat hij in de veronderstelling verkeerde dat de uitkeringen daaruit aan $[\mathrm{X}]$ zouden toekomen, en dat het onder die omstandigheden naar maatstaven van redelijkheid en billijkheid onaanvaardbaar is dat [de kinderen] zich op de aanwijzing als begunstigden beroepen. Deze oordelen zijn niet met elkaar in tegenspraak, [...].'

Latere verklaringen en gedragingen kunnen er niet toe leiden dat we via uitleg kunnen concluderen dat het ten tijde van de aanwijzing de bedoeling van $Y$ was om mevrouw $X$ te begunstigen. Wel kan uit latere omstandigheden volgen dat de kinderen zich niet op de begunstiging kunnen beroepen.

Wat maakt dit arrest van de Hoge Raad interessant? Allereerst lijkt de Hoge Raad bij de uitleg van begunstigingsclausules in levensverzekeringspolissen de erfrechtelijke uitlegmethode te verkiezen boven de contractuele (hierover onder meer Hoens, 'De verbroken relatie en begunstiging krachtens levensverzekering van de ex-partner', TE 2009/6, p. 95-102 en Asser/Wansink, Van Tiggele \& Salomons, Verzekering, 7-IX* 2019/726 e.v.).

Interessant is ook hetgeen Verstappen in zijn noot (NJ 2018/441) meldt over de wisselwerking tussen uitleg in het erfrecht en uitleg in het levensverzekeringsrecht en de rol daarbij van de derogerende werking van redelijkheid en billijkheid: 
'11. Dat erfstellingen in uiterste wilsbeschikkingen opzij gezet zouden kunnen worden doordat daarop geen beroep kan worden gedaan op grond van de beperkende werking van de redelijkheid en billijkheid, biedt perspectief voor de veel voorkomende gevallen waarin gesteld kan worden dat de testateur bij zijn overlijden inmiddels van mening is veranderd maar zijn testament nog niet heeft aangepast.' (Curs. FH)

Verstappen concludeert dat de Hoge Raad de deur - tot een rol voor de beperkende werking van redelijkheid en billijkheid bij het beroep doen op een duidelijke erfstelling 'minst genomen op een kier heeft gezet'.

Tot slot, relevant is evenzeer de les voor de verzekeraar die Kalkman (PJ 2018/161) uit het arrest trekt. Als de verzekeraar, voordat tot uitkering is overgegaan, kennis krijgt van een gewijzigde bedoeling (althans, gewijzigd ten opzichte van de oorspronkelijke bedoeling) zal deze geen uitvoering kunnen geven aan de oorspronkelijke begunstiging. Ook aanvaarding van de begunstiging door een oorspronkelijk begunstigde doet hieraan niet af. Bij twijfel over de persoon van de begunstigde, of zoals in onze casus discussie daarover, kan de verzekeraar de uitkeringsverplichting opschorten.

Tot de volgende keer!

mr. F.M.H. Hoens

Radboud Universiteit

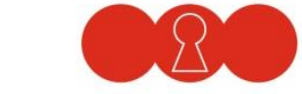

ScholsBurgerhartSchols

www.scholsburgerhartschols.nl

\section{Boomjuridisch}

\author{
Postbus 85576 \\ 2508 CG Den Haag \\ $\mathrm{T}(070) 3307033$ \\ E info@boomjuridisch.nl \\ I www.boomjuridisch.nl
}

Hoewel uiterste zorg is besteed aan de inhoud van AdvoTip - Erfrecht voor de advocaat aanvaarden de uitgever en de redactie geen aansprakelijkheid voor onvolledigheid of onjuistheid. 